\title{
Beyond the Color Line: A Postmodernist Reading of Ishmael Reed's Flight to Canada
}

\author{
Bi Boli Dit Lama Berté GOURE ${ }^{1}$ \\ ${ }^{1}$ Department Of Humanities, National Polytechnic Institute Félix Houphouet-Boigny of Yamoussoukro, Côte \\ d'Ivoire \\ Correspondence: Bi Boli Dit Lama Berté GOURE, National Polytechnic Institute Félix Houphouet-Boigny, \\ Yamoussoukro, BP 1093, Yamoussoukro Côte d'Ivoire. Tel: 225-0967-1550. E-mail: \\ benjamin3goure@gmail.com, boli.goure@inphb.ci
}

Received: June 23, 2020; Accepted: July 13, 2020; Published: July 15, 2020

\begin{abstract}
Though African American literature can be regarded by some theorists as a means of defining the racial self, a postmodernist reading of Ishmael Reed's Flight to Canada delves into the intrinsic value of that literature which supersedes the traditional racial connotation ascribed to it. Reed not only castigates the metanarrative of the American cultural and democratic thought through the exposure of its inconstancies and the criticism of traditional ideas on race and ethnicity, but he also gives proof of his creative genius by operating a carnivalization of the novel genre itself.
\end{abstract}

Keywords: ethnicity, metanarrative, deconstruction, carnivalization, cynicism towards orthodoxy

\section{Introduction}

African American literature has always been regarded as a means of defining the racial self. The truth of the matter is that African descents have been forced to resist the process of erasure of their cultural identity. Their literature is so intimately related to the issue of race that it becomes very difficult for any African American author to avoid being dubbed as a "black writer". Though some authors like Lorraine Hansberry have tried to reject that label, the average African American writer has always been assessed by the yardstick of race and ethnicity (Harris, 1997, 68).

Obviously, this situation has been encouraged by the African American writers and theorists themselves, who have long advocated a distinctive literature, deeply rooted in racial concerns. From its inception, with the rise of the slave narratives, African American literature has mostly been characterized by its political messages, sometimes to the detriment of artistry. The rise of the black aesthetics in the 1960s came to enforce the view that ethnicity is at the core of that literature. The movement was so radical in its Afrocentrism that it ended up in isolating African American literature, reversely encouraging its exclusion by those who wrongly tagged it as not being capable of rising above particularism.

Yet, a novel like Ishmael Reed's Flight to Canada undercuts the notion of identitarian closure often used as a defining feature of African American fiction. Reed himself is undoubtedly a controversial figure as he has always pursued his own creative ends "[...] finding it impossible to play the literary game by the rules of others" (Martin, 1988, 43). The Free-Lance Pallbearers, his very first novel, was published in 1967 at a time when the literary canons of modernism were being called into question, in an eclectic style combining syncretism, parody, pastiche and humor. This particular style was defined by Henry Louis Gates as the expression of African-American sensibility through the notion of the Signifying Monkey, a literary criticism approach elaborated in a book where he focuses on two figures of African American literature: Ralph Ellison and Ismael Reed (Gates, 1988). Reed himself also grounding his literary aesthetics in his African American identity, coined the term Neohoodooism to designate a writing style which is undoubtedly indebted to the broader literary construct of postmodernism as it can be seen through his cynicism toward orthodoxy, a behavior characterizing the period. Very prolific as a writer of fiction, Reed published other novels like The Terrible Threes (Atheneum, 1989), The Terrible Twos (St. Martin's Press, 1982) Mumbo Jumbo (Doubleday, 1972), Yellow Back Radio Broke Down (Doubleday, 1969) The Free-Lance Pallbearers (Doubleday, 1967), to name but a few, not only as a rich contribution to African American fiction, but mostly as a way of removing artificial barriers that had so far inhibited the black aesthetics. 
Written on the mode of the slave narrative, Flight to Canada assumes the horizon of expectations of the apology of black heroism. As its title may imply, the novel takes the reader back to the terrible condition suffered by enslaved people in the antebellum South, and which left them with no other option than fleeing to Canada: that peace haven where they could enjoy total freedom. As this horizon of expectations is not fulfilled, seeing the disillusionment of the characters who finally arrives in Canada, the beauty of the novel lies not just in the motifs and themes of the slave narrative which it parodies, but rather in the iconoclasm of Reed whose "[...] original and controversial contribution to African American letters [...]" could also be characterized as "[...] both participatory and adversarial [...]" (Fox, 1997, 624).

This article aims at showing that far beyond its racial undertone, the book published in 1979 is strongly indebted to the eclecticism of postmodernism, which is fortunate, in that it steers clear from the ethnic biases that normally twist African American thought, to reveal the depth of the cultural dynamics at work in African American fiction. Firstly, the discourse of Flight to Canada challenges the metanarrative of the American cultural and democratic thought and debunks common views on race and ethnicity. Then in the author's cynicism towards orthodoxy, he distorts the rules of the novel genre

\section{Resisting Metanarratives}

François Lyotard, the French theorist who immensely contributed to the formulation of the postmodernist thought, is said to have defined metanarratives as "discursive formations promising a totalized account of knowledge" (Childs, 2006, 186-187). History, which is regarded as a discursive formation, also arouses the distrust of postmodernists. Though it is said to be based on "critically examining and analyzing the records and survivals of the past" (Gottschalk 1969, 48), history is not always free from racial biases and assumptions as in the case of the United States. The rise of the African American historical novel in the 1970s came as a reaction to the racial prejudices and social stereotypes fostered by an enduring fragmented knowledge about African American experience. As Maggie Sale rightly put it:

History has been a contested terrain in which European American have had authority to define what is worthy of recognition, what may be considered of historical significance, and what versions or aspects of the past are important to keep alive in the present as a way of understanding who and what we are today (Sale, 1997, 358).

Though this historical novel intends to bring to light the rich contribution of some anonymous black people in the building of the nation, it shares with postmodernism the idea of contesting official discourses. Most of the time, the historical novel is a parody of the slave narrative; an "attempt at recuperation" according to the formula of Frederic Jameson, and which criticizes the American thought with some mockery as it is shown in the novel of Ishmael Reed (Jameson, 1991, xi).

\subsection{Inconsistencies in the American Democratic Thought}

Reed is certainly an atypical African American writer who is also known to have displayed an entire freedom from any dogmatic positions. His skepticism against totalizing discourses that pretend to hold the truth is evidenced in Flight to Canada which mixes historical figures namely Lincoln, Harriet Beecher Stowe, Frederick Douglass, Jeff Davis and Lee with fictitious characters like 40s, Stray Leechfield, Princess Quaw Quaw Tralaralara, Mammy Baracuda, Cato the Graffado, Yankee Jack etc., in order to invalidate some deeply rooted traditional American views (Reed, 1976, 7). The onomastics of the names of the characters as presented above hints at the ironic tone of the book as names of important people like Lincoln, Stowe, Douglass and Davis coexist with some eccentric and unpronounceable names like Princess Quaw Quaw Tralaralara or Cato the Graffado. Irony as an artistic device is used here to underrate and even contest the extent of the role that the above iconic figures are said to have played.

More than any other nation in the world, America's admiration for its Constitution knows no bounds. Yet, in the eyes of postmodernists like Reed, who contest any canonical considerations, history has proved that the United States is yet to "[...] rise up and live out the true meaning of its creed: 'We hold these truths to be self-evident, that all men are created equal"'(King, 1963). The issue of the peculiar institution, along with the injustice suffered by less privileged citizen including women and immigrants pinpoint the inadequacy of the American grand narrative.

Slavery in America is a contradiction with regards to the democratic and religious background of the American thought. Having fled the oppression and persecution of authoritarian regimes in Europe at a time when feudality was the order of the day, the choice of the Founding Fathers to build a nation on the foundation of liberty and equality is well understandable. So when that ideal is challenged by the bane of slavery, the historical discourse has to find some means to mitigate its effects, hence the conspicuous role given to the abolitionist movement. 
Historical accounts on this sad episode in the experience of the American nation, clearly show the important part taken by some white figures like William Lloyd Garrison, Wendell Phillips, Harriet Beecher Stowe and more importantly President Abraham Lincoln, in the emancipation of African slaves.

Stanley Harrold's recent publication on the subject of abolitionism not only shows its topicality and complexity, but also agrees on the fact that even though the movement would quickly become an interracial endeavor, it was originally headed by white leaders (Harold, 2019, 2). Furthermore, Richard S. Newman who highlights the contributions of two organizations namely the Pennsylvanian Abolition Society and the Massachusetts Antislavery Society to the constant evolution and adaptation of abolitionist ideas and strategies, pays tribute to William Lloyd Garrison's ceaseless efforts in view of the eradication of slavery. He made it clear that "In both the popular imagination and in many scholarly accounts; Garrison's debut remains the benchmark of abolitionism" (Newman, 2002, 1).

Surprisingly, some of those iconic figures are ridiculed through their fictionalized forms in the novel of Reed. Obviously, this attitude of Reed originates from the skepticism of postmodernist writers who do not hesitates to challenge official versions of historical facts by rewriting history. But it also underlines the political manipulations and hypocrisy in relation to the idea of abolitionism itself, which once moved Pulitzer Prize winner and historian James Mc. Pherson to assert that not all "the adherents of the all spectrum of antislavery sentiment" could be rightly described as abolitionists (Mc Pherson, 2014, 22).

Abraham Lincoln is one of the most respected figures of American history, for having paid his engagement for the cause of African slaves with his own life. Yet, the fiction of Reed challenges the official history about this heroic figure who has often been idealized, like most of the iconic figures, because they embody some important values. For instance, some rumors have been spread about him being an illiterate, a drunkard, a mad, a womanizer or a "nigger" (Reed, 1976, 7). Obviously, those rumors have been spread by his opponents like the Confederates, and they can in no case be taken for granted. Yet, they are sufficient reasons to doubt the official history: "Who is to say what is fact and what is fiction [...]" (Reed, 1976, 7). The fictitious Lincoln visits Arthur Swille, a white slaveholder of the South, who is also a rich aristocrat, not to convince him to emancipate his slaves, but to borrow some money from him in order to finance the war.

Lincoln is also suspected of having a dubious attitude and an ambiguous position toward slavery. Though he has voiced his opposition to slavery, he easily condones the evil in order to gain the favor of a potential creditor: "Well Mr. Swille, if you've read my campaign literature, you'd know that my position is very clear. What a man does with his property is his business" (Reed, 1976, 35). Of course, there is nothing wrong with a man defending his right to property, but when those belongings also include his fellow human beings, any justification whatsoever amounts to cheer cynicism. And to add injury to insult, Lincoln is credited with the following assertion which he does not contradict:

You yourself, Mr. President, said that you were never in favor of bringing about social and political equality with them. You don't want them to vote, either. I mean, I read that in the newspaper. They are not like us, Mr. Lincoln. You said yourself that there are physical differences (Reed, 1976, 38).

The above accusation to which Lincoln reacts by admitting that he is "a little wishy-washy on the subject still" underlines the failure of the American leadership when it comes to defending the spiritual values promoted by the American democratic thought against financial interests. Lincoln might well point out that he is the representative of the "[...] Republic people in this great people period [...]" (Reed, 1976, 29), it is rather the aristocrats who rule the nation, thus invalidating the ideal of the government of the people by the people. The hypocrisy of the system is evidenced in the fact that Abraham Lincoln, one of its celebrated representatives, collides with Arthur Swille III, the representative of the Feudal order.

Arthur Swille III is an absolutely disreputable figure opposed to democratic values. In a nation that promotes justice, equality and freedom, this descendant of people who treated their "[...] serfs like human plows and debudded their women at will [...]" is a misfit (Reed, 1976, 16). From the history of his ancestors, he is the perfect single-minded essentialist who has inherited the racism, the sexism and the religious bigotry of his parents. While he treats his slaves like properties or mere objects, his wife's sympathy for the suffragette movement and the writings of Harriet Beecher Stowe indicates that despite the ideal of democracy, America has once been a strictly patriarchal country. By painting the character of Arthur Swille in a book which follows the tradition of the African American slave narrative, Reed gives a new vision of the race issue which he includes in the broader construct of the American problem. 


\subsection{Deconstructing Deep-Seated Ideas on Race and Ethnicity}

A book written about the antebellum South cannot ignore discourses that try to justify the peculiar institution. Dominant constructs in favor of the exploitation of African slaves as belongings, voluntarily ignore their unalienable rights to the pursuit of happiness in a country they have helped build. The African American novel generally tries to expose the partiality of those discourses. But the merit of Flight to Canada lies in the fact that it does not settle for a black essentialism. On top of denouncing the prejudices suffered by black people, part of Reed's innovative and provocative literary aesthetic lies in his depiction of some negative black characters, a decision that was strongly criticized by critics of the new black aesthetic movement (Martin, 1988, 60).

The issue of the exclusion of African Americans comes from their being originally considered as simple workhorses to ploy the farms and mere properties to be traded when necessary. Treating their fellow human beings like commodities remained problematical even for the adamant supremacists of the South who needed to soothe their conscience by finding a justification in some discourses. No other means could better serve the purpose of the racists than the authority of science.

When Uncle Robin, Arthur Swille's black butler, unexpectedly inherits the castle and everything behind the gates of his master's estate, the judge who comes to read the will, reveals his prejudiced mindset by asking a delicate question: "Science says [...] well, according to science, Robin, the Negro doesn't [...] well, your brain - it's about the size of a mouse's. This is a vast undertaking. Are you sure you can handle it? Juggling figures. Filling out forms [...]" (Reed, 1976, 167). What is at stake here is not the capacity of Robin to run the castle, since this is exactly what he has been doing for years, when his master was still alive. The judge is rather eager to perpetuate the supposed inferiority of the Black; and calling to science is of no use here because the fortune of Robin comes from his wise use of circumstances consequently from this intelligence which has been denied him.

The irony of the situation lies in the mistake made by the racists in thinking that slaves are a bunch of submissive and childish people. Knowing Arthur Swille, there is no way he could have allowed his negro butler to own this castle which is "[...] the very replica of King Arthur's in the Holy City of Camelot, the Wasp's Jerusalem, the great Fairy City of the old Feudal Order [...]" (Reed, 1976, 15). Relying on this conceited idea of the naivety of black people, he then untrusted Uncle Robin with some sensitive issues like his account books as well as some other legal matters, not knowing that the latter would take advantage of his master's dyslexia to change the terms of his testament:

God helps those who help themselves [...] I dabbled with the will. Well, if they are not bound to respect our right, then I'll be damned if we should respect theirs [...] Well anyway, Swille had something called dyslexia. Words came to him scrambled and jumbled. I became his reading and writing. Like a computer, only this computer left itself Swille's whole estate (Reed, 1976, 170-171).

Convinced that his butler was as innocent and docile as his compatriots, he could not have distrusted him. The truth of the matter is that this fallacy about the inability of black people was a huge swindle orchestrated by the white majority to deny them of their position in mainstream America. This injustice has not eluded Reed who recalls the story behind the publication of Harriet Beecher Stowe's famous Uncle Tom's Children. Contrary to the official version which states that the author was inspired by the life of Josiah Henson, Reed suggests that she rather plagiarized him:

The story she "borrowed" from Josiah Henson [...] She's read Josiah Henson's book. That Harriet was alert [...] It was short but it was his. It was all he had. A man's story is his gris-gris, you know. Taking his story is like taking his gris-gris [...] Josiah would never have thought of waging a plot-toting suit against her (Reed, 1976, 8).

In trying to deconstruct all kinds of logocentric ideas, even the abolitionist movement is not spared as evidenced by the accusation against Harriet Beecher Stowe. In their efforts to free the slaves from the antebellum South, the abolitionists had set up a network referred to as the Underground Railroad, to help them join Canada, where they could be free at last. Yet the novel destroys the myth of an antislavery Canada. It is argued that the country's big companies being possessed by American businessmen, they had certainly influenced and corrupted the place, which could not certainly be in favor of fugitive slaves.

There are even some vigilantes described as being even worse than the Klan people back in the United States. Not only are they racist activists, but also their racism is more severe, since it is not directed against the black race only: "They beat up Chinamen and Pakistani in the streets. West Indians they shoot" (Reed, 1976, 160). All this bad report is made by a disillusioned former slave by the name of Carpenter who is set to go back to America and 
ready to face the bloodhound slave hunters of the South. No other setback could be worse than escaping to Canada, only to find that the country is not the dreamland so desired.

As his reputation of iconoclast might suggest, Reed is not just interested in a pro-black message, flawed by a long standing dualism, taking for granted, the innocence of black people. The common idea that stipulates that all those who escaped slavery and later wrote about their ordeal, have to be regarded as heroes, is questioned. Though, no famous former slave is named and parodied as with Abraham Lincoln or Harriet Beecher Stowe in the case of white abolitionists, the fiction of Reed insinuates that some black people, especially those who were born of white parents, often joined the abolitionist movement for some sordid and disgraceful profits (Reed, 1976, 91). Without sparing anybody, Reed's fiction even ventures into mentioning the existence of black slaveholders: "The slavemasters in Louisiana often freed their sons by African women. Some of these children became slave owners themselves" (Reed, 1976, 91).

Moreover, while one would have expected that former slaves adopt a common front against injustice, the case of Quickstill, 40s and Leechfeeld -- three fugitives who escaped from Arthur Swille's plantation - and are incapable of taking a common stand against the bloodhounds sent after them by their master, epitomizes the lack of cohesion among the black community:

Cause them nigger don't want organization. You have a organization, they be fighting over which one gone head it; they be fingtin about who gone have the money; then they be complainin about things, but when it come down to work, they nowhere to be found. Look, Quickstill, they bring in some women, then it's all over (Reed, 1976, 79).

The above passage dealing with the reaction of 40s to the call of Raven Quickstill, the protagonist, underlines some issues plaguing the community like cynicism of some individuals, lack of good leadership, inaction of some members and failure of the men to fulfill their responsibility in the family. Finally, Reed concludes in denouncing the victimization which is common among African Americans, as he gives the floor to a Russian born Jew who displays all the racial prejudices and injustices he and his fellows have had to undergo even in the New World. Going further in this analysis shows that Reed's iconoclasm equates his eclectic writing.

\section{Carnivalisation or the Subversion of the Novel}

Though Flight to Canada embraces the spirit of the historical novel, Reed its author could not be expected to stay loyal to this sub-genre. His eclectic writing style is evidenced here in his choice of the parody. Known as an "Imitation of a particular style or genre for the purpose of satirizing it", this literary device implemented in the novel clearly show Reed's desire to contest conventional ideas of forms and genre (Quinn, 2006, 314). Furthermore, discontinuity and heterogeneity are the two terms which best characterize the novel. Key aspects of the genre such as storyline and timeline undergo some serious disruptions, thus epitomizing the author's disrespect for the principle of structure as a stable and coherent system.

\subsection{Disruption and Discontinuity: Invalidating the Linear and Sequential Fashion}

Traditionally, the slave narrative revisited by Reed and other African American authors, through the neo-slave narrative, has some autobiographical undertones. Its storyline is well structured as the subject matter is the life of a former slave who escapes slavery and later writes about it in order to sensitive the opinion about the dehumanizing conditions of slave life. Sentences like "I WAS BORN IN Tuckahoe near Hillsborough, and about twelve miles from Easton, in Talbot County, Maryland" (Douglas, 2009, 15). Or "I was born a slave on a plantation in Franklin County, Virginia [...]" (Washington, 2009, 20) dictate the structure of the book which embraces the normal course of the life of their heroes. Some conspicuous steps which are birth, earlier life in slavery, awareness, flight and fight for the cause, punctuate the plot.

With Reed's novel, the disruption appears from the onset of the book, since some steps are truncated from the normal course of events. Though the incipit introduces a first person narrator as with an autobiography, this fictionalized form of narrative rather hovers around some aesthetic issues presented by Raven Quickskill, the protagonist of the book, who happens to be a writer. There is no paragraph that could serve as a presentation of the autobiographer not to mention the silence about the motive behind the story. In fact, of all the sequences earlier alluded to, only flight is dealt with as Raven Quickstill is obsessed with his crave for freedom symbolized by Canada.

Flight to Canada is definitely not a plot-oriented narrative revolving around the life of a single character, not even Raven Quickstill, its protagonist. Had that been the case, the storyline could have started with an exposition presenting the most important characters as well as their respective role in the story. Instead, the names of 
characters are given with no apparent hierarchy. Only through an effort of construction of the significance is the reader able to understand the relations among them.

As for what motivates the characters in their actions, the idea of the story as a structured sentence advocated by A. J. Greimas, with some characters acting as the helpers of the protagonist and others as the opponents to his quest, cannot simply be applied here, since there is no unified course of action, no single object serving as the catalyst of the action (Greimas, 1983). The truth of the matter is that this is not a single and unified storyline about the incidences in the life of a former slave who enjoys the help of some benefactors and overcomes all the obstacles raised by his quest, in order to obtain the desired victory trough a heroic impetus. Even though the title of the book is reminiscent of the topic of slavery, the dehumanizing conditions of slave life, which serve as the background of the traditional conflict for slave narratives, is not what connects the events in a book, where those events are not arranged in an orderly manner. As this novel is indebted to the postmodernist concept of discontinuity, it then rejects the notion of "[...] formal ordering of the content in time [...]" which characterizes traditional literature. Consequently, the linear form is abandoned for a fugal form taking "[...] liberties with chronology" (Childs, 2006, 92).

The book is supposed to deal with the story of Raven Quickskill, a former slave who is "[...] the first one of Swille's slaves to read, the first to write and the first to run away [...]" (Reed, 1976, 14). His flight occurs during the period of the Civil War, but when the book opens, the war has already ended and outstanding events in relation to that historical period have already taken place. Quickstill, being a writer by profession, have been entrusted by Uncle Robin, another former slave who have inherited a huge estate from Swille their master, to write his biography. Had the novel followed the linear pattern in presenting first things first, the beginning of the book should not have presented the end of the story.

In fact, the book closes on page 179 with Uncle Robin, the new master of the castle who has now become affluent, when it is all said and done. This is normally where Raven should be ordered to write the story of Uncle Robin. Of course, any narrative is a retrospective relation of some events which are supposed to have happened at an earlier time. But Reed skips the normal exposition that should prepare the horizon of expectations of the reader with regards to the traditional biography, thus starting the narrative by a sequence which should normally intervene at the end of the story. Then the story evolves on the pattern of a crossover between life at the castle in Virginia and the different stations or hideouts of Raven in his flight with some flashbacks of larger or smaller spans.

The literary choice inevitably results in the overlapping of different and sometimes distant time periods. As form often fits with content, this fugal form is a way of challenging the authority of the narrative of history. In the same vein of contesting history, Reed mixes facts with fiction. The end result of this aesthetics are some improbable situations where the radical boundaries of time are crossed. How could Edgar Allan Poe be the biographer of the Civil War as suggested by Raven Quickskill on page 10, since he had died in 1849, some years before the war even started? Only in a story where no attention is paid to the basic principles of lifelikeness can we see an African American slave of the nineteenth century driving a carriage with all the gadgets of a modern car:

[...] Dressed up like a gentleman, smoking a seegar, and driving a carriage which features factory climate-control air conditioning, vinyl top, AM/FM stereo radio, full leather interior, power-lock doors, six-way power seat, power windows, white-wall wheels, door-edge guards, bumper impact strips, rear defroster and soft-ray glass (Reed, 1976, 36).

In fact, Stray Leechfield, the character depicted above is not the only one who, by dint of some magic realism, is made to use some inventions which will appear long after his time. While Raven Quickskill uses a Xerox machine to keep a copy of his poem (Reed, 1976, 52), Uncle Robin and Aunt Judy watch a TV show where a panel is discussing the Emancipation of the slaves. (Reed, 1976, 56). The climax of this carnivalization is found at the very beginning of the book where two far remote time periods namely the year 1850 and the year 1977 are mentioned in the same chapter in the account made by Raven Quickskill on the form of a chronicle about the ancestry of Arthur Swille (Reed, 1976, 16-17).

The anachronisms which originate from the refusal to adopt a consistent chronology, points to a more complex theoretical concern, namely the skepticism of postmodernists toward master-narratives. According to Christopher Butler, in challenging the closure of historical constructs they mix "[...] historical and fictional material [...]" (Butler, 2002, 70), thus creating a distinctive genre which Linda Hutcheon refers to the "historiographic metafiction" by which she means "[...] those well-known and popular novels which are both intensely selfreflexive and yet paradoxically also lay claim to historical events and personages [...]" (Hutcheon, 1988, 5). 


\subsection{Carnavalisation and Cynicism Towards Orthodoxy}

The defining criteria of any work of fiction, including the novel, is basically the relation of invented or imagined events as opposed to factual events (Quinn, 2006, 164). As a matter of fact, no knowledgeable reader can reasonably look for truth in a work of fiction, as it is commonly taken for granted that the realism of the characters and the scenes therein are mere pretense. In the words of Raven Quickstill, the writer portrayed in this novel of Reed, who could also be considered as the mouthpiece of the author: "[...] who is to say what is fact and what is fiction". In a novel which pretends to give another version of history and truth as opposed to commonly accepted views about key historical events like the Civil War and distinguished historical figures like Harriet Beecher Stowe or Abraham Lincoln, the issue of truth versus fallacy could be raised.

Yet, there is no real debate as to what extent is the story of Reed true as far as those figures and events are concerned. The pursuit of truth is simply impossible in the work of fiction which inherently fosters invention. What is more, Raven Quickstill is not going to lure anybody in forcing them to believe in his story by pretending that there is some truth in his version which should be taken as the revelation of some hidden truth about the origin of a cornerstone of American fiction like Uncle Tom's Cabin. In stating that "New disclosures are as bizarre as the most bizarre fantasy [...]" (Reed, 1976, 8), he intends to bring his readers to the realization that they may have been misled by the official version. Furthermore, in anticipating the disbelief of his readers who might deem his story as far-fetched, he warns them that new disclosures sometimes take people by surprise and leave no other choice than giving the feeling of not being credible, while they really are. This uncommon overlapping of past and present, fiction and fact, testifies to Reed's heterogenic writing style which inevitably adulterates the novel genre. Decidedly, Reed's novel is a vast experimental field of the postmodernist idea of heterogeneity and hybridity.

Furthermore, his borderline inquiry is seen through the inclusion of different materials borrowed from other literary genres in order to cohere with the overall philosophy of heterodoxy. In fact, if any originality there is in the writing style of Reed, this is obviously not to be found in the uniqueness of his text, but rather in its breaking of conventions. As stated earlier, the subject matter of slavery as it affects the slave who tries to escape and later writes about his ordeal is indebted to the tradition of slave narratives. More also, the text of Flight To Canada espouses the language of the genre as Raven Quicksquill is entrusted with the mission of writing the biography of a former slave who have become affluent (Reed, 1976, 11). Moreover, Quickskill and two other slaves have the destiny of all the fugitive slaves that their masters always try to repossess (Reed, 1976, 61). The slave escapees also enjoy the assistance of good-willed people in a place called Fort Thunderbind, a refuge for slaves where they can receive their Emancipation papers (Reed, 1976, 93).

Nonetheless, the conspicuous reference to the slave narrative genre should be seen as part of the various influences of Reed as it does not prevent him from using adaptation, a literary practice inscribed in the broader framework of intertextuality. Flight To Canada, this long work of fiction, largely influenced by the slave narrative, stars with the poem entitled "Flight to Canada" as an incipit. Adaptation, the fact of including prose and poetry in the same book is further evidenced by another poem entitled "The Saga of Third World Belle, which occurs in chapter Nineteen and on page 123, just after a page left blank for no apparent reason. In the book, the barriers between the theater, and the novel vanish when Reed mixes the dialogues of a play shown on television with the conversation and the description of a love scene between Quickskill and Quaw Quaw from, page 99 to page 103.

Apart from imitating the formulaic structure of the slave narrative, Reed further parodies some well-known literary works like the myth of King Arthur by naming the wealthy and influential slaveholder of his story after him (Reed, 1976, 15). Through this controversial figure, Reed questions the American democratic thought as he pinpoints the corruptive influence of the new aristocracy on democracy. Moreover, he explores the dark side of humanity when he borrows the formulaic structure of the story of Shakespeare's Hamlet to denounce the cynicism of the new American bourgeoisie, ready to sacrifice all moral values for their unlimited ambitions. He also shares the inclination of the postmodernists for freaks as he portrays the specter of Arthur Swille's dead son who appears to his mother. Like the father of Hamlet, he emerges from the world of the dead to reveal the very reasons of his misfortune. Unlike the dead king, Arthur's unfortunate son appears as a real freak since he wears the skin of the crocodile who murdered him (Reed, 1976, 125-128).

The typology of the first pages of this chapter written in italics also testify to this decision to jettison the rules of the genre. The use of the italics could be explained by the fact that the passage which goes from page 7 to 11 is an instance of metafiction, as it offers some information about the genesis of Uncle Tom's Cabin as well as the outcome of "Flight to Canada", and the way it has entirely changed the destiny of Raven Quicksquill, to the point of making him an authorized biographer and a confirmed writer. He can now have the rich and profitable career of Carpenter which he has always dreamt about. This Carpenter is a freed Negro whose writing style embodies the 
heterodoxy of Reed himself: "He was so much against slavery that he had begun to include prose and poetry in the same book, so that there would be no arbitrary boundaries between them" (Reed, 1976, 8). His characters being writers themselves, this gives a self-reflexive undertone to the book which at times resemble more to a critical work than to a fiction book. This much is sure: Reed's creation is highly hybrid and self-reflexive with a lot of intertextuality adopted from other literary genres. This is an indication of the "borderline inquiries" he chooses to embark on. With Flight to Canada, "the borders between literary genres have become fluid [...]" (Hutcheon, 1988, 9).

\section{Conclusion}

Reed's novel is deeply entrenched in the tradition of the slave narrative and its pro-black message of the recognition and the defense of the rights of African American people. Yet in taking a stand against every dogmatic position, he debunks this black essentialism while invalidating all predominant constructs as he denounces racism as well as the hypocrisy of the American democratic thought. In his cynicism against conventional ideas of forms and genre, the basic rules of the novel have been jettisoned.

His postmodernist aesthetics of discontinuity and heterogeneity have imposed some serious disruptions to storyline and timeline, those key components of any fiction work. Furthermore, in his choice to parody the Slave Narrative, Reed has offered a conspicuous role to intertextuality through several instances of adaptations which not only testify to his "borderline inquiries" but also open African American literature to other possibilities. Consequently, if the borders between literary genres could become fluid, the hybrid novel thus obtained epitomizes the need for the interpenetration of cultures as a solution to the human tragedy of essentialism.

\section{References}

Butler, C. (2002). Post Modernism, A Very Short Introduction, Oxford: Oxford University Press.

Childs, P., \& Roger, F. (2006). The Routledge Dictionary of Literary Terms, London: Routledge. https://doi.org/10.4324/9780203462911

Douglas, F. (2009). Narrative of the life of Frederick Douglas, an American Slave, Written by Himself, London: England, The Belknap Press of Harvard University Press, Reprint.

Fox, R. E. (2017). "Reed Ishmael" in African American Literature, Oxford: Oxford University Press.

Gates, H. L. (1988). The Signifying Monkey, Oxford: Oxford University Press.

Gottschalk, L. (1969). Understanding History: A Primer of Historical Method, $2^{\text {nd }}$ Edition, New York: Knopf

Greimas (Algirdas Julien), Du sens II, Paris: Ed. du Seuil, 1983.

Harris, W. J. (2014). "Black Aesthetics" in African American Literature, Oxford: Oxford University Press.

Harrold, S. (2019). American Abolitionism, Its Direct Political Impact from Colonial Times into Reconstruction, Charlottesville: University of Virginia Press. https://doi.org/10.2307/j.ctvcszzs0

Hutcheon, L. (1988). A Poetics of Postmodernism, New York: Routledge

Jameson, F. (1991). Postmodernism or the Cultural Logic of Late Capitalism, Durham, Duke University Press. https://doi.org/10.1215/9780822378419

King, M. L. (1963). "I Have a Dream". Retrieved Jun 22, 2020 from https://www.archives.gov/files/press/exhibits/dream-speech.pdf

Martin, R. (1988). Ishmael Reed and the New Black Aesthetic Critics, London: The Macmillan Press Ltd. https://doi.org/10.1007/978-1-349-19166-6

Mc, P., \& James, M. (2014). The Struggle for Equality; Abolitionists and the Negro in the Civil War and Reconstruction, Princeton. New Jersey: Princeton University Press; Reprint.

Newman, R. S. (2009). The transformation of American Abolitionism, Fighting Slavery in the Early Republic, Chapel Hill: The University of North Carolina Press.

Reed, I. (1976). Flight to Canada, New York: Scribner Paperback Fiction.

Sale, M. (2006). "Historical Novel" in African American Literature, Oxford: Oxford University Press Quinn, Edward (2006) A Dictionary of Literary and Thematic Terms, New York: Facts on File, Inc.

Washington, B. T. (2009). Up from Slavery, New York: The Floating Press, Reprint. 


\section{Copyrights}

Copyright for this article is retained by the author(s), with first publication rights granted to the journal.

This is an open-access article distributed under the terms and conditions of the Creative Commons Attribution license (http://creativecommons.org/licenses/by/4.0/). 